\title{
Create Teaching Creativity through Training Management, Effectiveness Training, and Teacher Quality in the Covid-19 Pandemic
}

\author{
Hasmin Tamsah ${ }^{1}$ and Jamaluddin Bata Ilyas \\ Sekolah Tinggi Ilmu Ekonomi AMKOP, Makassar, Indonesia \\ Yusriadi Yusriadi \\ Sekolah Tinggi Ilmu Administrasi Puangrimaggalatung, Makassar, Indonesia
}

\begin{abstract}
Using an online survey, the study examined creativity in adapting the teaching and learning model during the COVID-19 pandemic in Indonesia. The research used an online survey of civil servant teachers, honorary teachers, and contract teachers, using a nonprobability sample. The responses of 417 respondents were analyze using Structural Equation Modeling (SEM) Amos. The learning system was carried out remotely using information technology. The study found that management, efficiency, quality, increased during the Covid-19 pandemic. The study argues that paying attention to the suitability of methods, training participants, quality of content, and improving impacts teaching-and-learning effectiveness.

Keywords: teacher, creativity, quality, training, management, effectiveness, Indonesia
\end{abstract}

Teachers have been unable to use all learning models during the COVID-19 pandemic because distance has limited interactions with students. Therefore, creativity is needed to take advantage of different learning models to deal with conditions during the COVID-19 epidemic, such as blended learning. The limited use of face-to-face (conventional) models is replaced by online learning (Van Bruggen, 2005). Teaching creativity during the COVID-19 pandemic will increase students' motivation to learn (Favale et al., 2020). Creativity also impacts learning achievement and has a direct or indirect effect on improving the quality of education. However, given the presencee of students with varied skills, the learning process requires that teachers' uses' (methods, time, material simplification creatively) generate motivation, process quality, and highquality learning outcomes.

Although teachers can provide teaching creativity, a qualified teacher cannot be formed just like that. Developing creativity and use creative methods requires a long series of processes. For example, even though you already have adequate educational qualifications as a teacher, you need additional experience, skills, and knowledge. Training is one of the most common methods, but proper training requires good management to achieve a good result. Furthermore, only practical training will produce a high-quality teacher and ultimately stimulate good teaching creativity (Thomas \& Cheese, 2005). Teaching creativity for teachers is an essential part of the teaching and learning process (Dehaan, 2009). Creativity is a necessary aspect of human development (Sternberg, 2003). Therefore, the creativity model that teachers are applying in teaching and learning activities, especially during the COVID-19 pandemic, is an interesting and necessary topic. Not all teachers during the COVID-19 pandemic have managed distance learning well (Daniel, 2020). This happens because many teachers have limitations in the use of information

${ }^{1}$ Corresponding Author E-Mail: hasmintamsah@gmail.com 
technology.

This research articulates some of, the advantages and disadvantages of learning practices. As a result, teachers will be better able to evaluate their methods to improve teaching and learning process activities. This study aims to reveal a series of processes that teachers carried and their policies. This study explores the relationship between training management, training efficiency, teacher quality, and teaching creativity, during the COVID-19 pandemic. Although much research on teacher performance training has been done, training management and teacher quality and their relationships to training efficiency are lacking. This research helps to fill this gap.

\section{Literature Review}

\section{Teaching Creativity}

In theory, teachers must be well-versed in the topic of teaching imagination. Creativity is transforming an existing definition into a new one, for example, when two old reports have been merged to form a new meaning (Livingston, 2010). Creativity is the product of interactions between individuals and their surroundings, the ability to create new combinations based on data, details, or elements that already exist or are previously established, namely all a person's life experiences and knowledge.

The term "teaching" refers to managing and organizing the surrounding environment to grow and promote the teaching and learning process. There are two phases to the teaching process (Dehaan, 2009). First, the teaching process is carried out to establish students' learning opportunities by using the environment as a supporting factor. Second, learning conditions are selected such that the teacher's guided teaching actions can achieve the intended learning objectives. Teaching innovation is the ability to develop a mixture that creates a new idea of a deliberate process to provide students with the opportunity for the learning process to take place in conjunction with the objectives that have been established.

Teacher teaching innovation is a competency playing an essential role in achieving the desired learning effectiveness based on the learning goals and school curriculum. Learning achievement is the product of a teacher-managed method of transforming the learning treatment. Teachers, through their creativity, provide students with learning treatment in the form of changing instructional materials, behaviors, personality, discipline, and exemplary behavior (Simonton, 2012). The more skilled and imaginative the teacher is in providing learning treatment, the better the results will be. On the other hand, the less professional and creative the teacher is, the worse the results will be.

A creative teacher holds the following qualities (Jeffrey \& Craft, 2004). These are fluency, which is the capacity to produce many thoughts, answers, and problem-solving solutions from one's mind, as well as provide multiple suggestions for doing different things. 2) adaptability, i.e., the ability to address problems using various methods, consider multiple solutions, and adjust one's way of thinking. 3) originality, which is the ability to give birth to new and creative expressions, think of unusual ways to convey oneself and combine parts or components, and 4) elaboration, or the ability to create an idea or product and detail an object, idea, or circumstance to make it enjoyable. 


\section{Teaching Creativity Factor}

Teachers who are innovative in their teaching practices are more than likely to meet competency standards than those who are not innovative. Three conditions affect the development of teacher creativity in teaching (Gustina \& Sweet, 2014). The first is professionalism. Professionalism means that teachers have teaching experience, master numerous teaching and learning techniques and models, are wise and innovative in discovering ways. They can handle learning activities individually and in groups, emphasize high expectations of achievement for any opportunity, and master techniques and study models. Second, they have a distinct personality. These characteristics include being open to new experiences, being sensitive to children's growth, having broad concerns, being attentive, having tolerance, high imagination, and being curious. Third, they develop social relationships, which involves being fond of and successful in associating with gifted students with all their anxieties, knowing these students, being adaptable, easy to get along with, and quickly understanding others' actions.

Creativity arises because of the many factors influencing it. In general, the development of different talents, behaviors, and a strong positive interest around work occupied, and the desire to carry out tasks affect creativity (Simonton, 2012). Several factors affect teacher creativity production: 1) The job environment helps teachers expand their experience and expertise in completing assignments. 2) effective collaboration among educational personnel in resolving problems. 3) recognizing and encouraging any positive effort made by teachers to increase student achievement. 4) providing teachers with the confidence to develop themselves and demonstrate innovative work and ideas. 5) delegating significant authority to teachers to carry out tasks and solve problems that arise when carrying out tasks, and. 6) allowing teachers to create policies regulating educational practices in schools, especially those about learning achievement.

In essence, if the task is prepared ahead of time, the goal will be guided and efficient. A teacher must be creative to plan lessons. A teacher should design teaching programs and make teaching plans before starting to teach. Learning preparation is the practice of scheduling content, media, teaching approaches, or methods in advance for use in the following semester to achieve predetermined goals (Livingston, 2010; Tamsah et al., 2020). Learning preparation requires techniques that identify the objectives that a teaching activity will accomplish, the strategies it will use to measure the achievement of these goals, the material to be provided, how it will be delivered, and the media necessary.

\section{Theoretical Background and Hypothesis Development}

This research's main concern is teaching teachers' creativity, especially during emergencies caused by the COVID-19 pandemic. The study's rationale refers to human capital theory, consisting of individual capacity, individual motivation, climate organization, workgroup effectiveness, and leadership (Šlaus \& Jacobs, 2011). Some believe human capital theory has not adequately explained human resources. Some believe that this theory has limitations and problems with the approach (Tan, 2014). Another view is that human capital theory has implications for developing the education system by focusing on skills and individual characteristics as assets for companies that will increase productivity (Bohacek \& Kapicka, 2008). Based on this view, this research was carried out starting with training and then, at the very end, the creativity of teaching the teacher to produce productivity.

Training research has been conducted extensively, such as its relationship with employee performance (Brown et al., 2015; West \& Blackman, 2015) and its relationship with training 
effectiveness (Nigam \& Ghani, 2000; Scott et al., 2004). Some research has found that, environmental training factors and motivation for training, may encourage training effectiveness (Gagné, 2009; Pencheon \& Koh, 2000). Also, the categories of group work, interaction, participation, illustrations, and demonstrations encourage training effectiveness (Van Der Klink \& Streumer, 2002). Furthermore, the training environment, the work environment, and employees' characteristics can promote training effectiveness (Vorontsov \& Vorontsova, 2015; Zacharias et al., 2021).

Various training and their impacts on the creativity of teachers have been carried out. Good training management is carried out by paying attention to the method's suitability concerning the type of training, the participants, the quality of the excellent training content, and the trainer's quality. Studies have shown that the method's appropriateness with the participants and the type of training can contribute to an activity (Barro, 2001; Hannah, 1987). Others have shown that quality of training content (Joll et al., 2018; Wößmann, 2003) and trainers' quality are important concerning training effectiveness (Chatani, 2012). As a result, the accuracy of training methods, the quality of training content, and trainers' quality are essential aspects of training quality. The following hypothesis is posited:

\section{Training Management Has a Direct Effect on the Effectiveness of Training}

Practical training with good management has an impact on improving the quality of teachers. Practical training will result in teacher professional development that focuses on knowledge and content of experience to make it more effective in teaching (Ur, 1992). Also, the effects of different education and training types encourage teachers' productivity to increase student achievement (Juklová, 2015); this signifies that the teacher is qualified to do so.

Training effectiveness can facilitate the development of a creative process (Dinda, 2014), i.e., teaching creativity can encourage students to learn creatively (Brinkman, 2010). This evidence shows that training designed with good governance will produce effective training. This practical training will produce a quality teacher so that he/she can develop creativity in teaching. Teachers may be educated after graduation, but it takes time and training to become professional teachers (Guskey, 2002). As a result, a quality teacher does not just happen but requires a strenuous effort through training.

Several research findings on teacher quality have shown teachers' educational skills concerning educational experience and qualifications (Dobson, 1985). Other studies have also shown that the quality of teachers characterized by education, recruitment, and professional development is correlated with student achievement (Hollins, 2011). In the meantime, the level of education has academic skills or knowledge that are markers of teachers' who are more effective in the classroom (Zhao et al., 2017). Also, teachers' quality is characterized by experience, education, skills, and teachers' certification (Wiswall, 2013), which impact the effectiveness of teaching and student achievement. Therefore, in this study, teachers' quality was measured by indicators of skills, knowledge, experience, and education. Thus, the following hypotheses are posited:

\section{Training Effectiveness Has a Direct Effect on Teacher Quality}

Educational institutions must try to obtain qualified teaching staff because teachers' quality can encourage a quality teaching and learning process. Previous research has shown that a qualified teacher can promote teaching creativity with various teaching behaviors and increase learning 
outcomes with higher test scores (Florea \& Hurjui, 2015). Other studies have shown that the quality of teachers certified by formal certification bodies impacts their teaching effectiveness compared to those without certification (Ucus, 2015).

Teacher quality is achieved not instantaneously but through a long process. Teacher quality can produce cognitive flexibility, which, in turn, will results in creative behavior, including innovative teaching (Baer, 2020). Teacher quality, characterized by skills, knowledge, experience, and education, is built on competence, while motivation is the driving force behind creativity (Schipper, 1984).

Teachers' teaching of creativity is also interpreted as pedagogical competence (Brent \& Leedy, 1990). Imagination is defined as the ability to use learning methods that are fun for students (Simonton, 2012) or using attractive learning designs (Mohammad et al., 2015). Another view is that teacher creativity can combine different skills from knowledge, attitudes, and social aspects (Flournoy et al., 2000). Teachers ' teaching creativity in this study is teachers' ability to manage and generate new ideas in delivering the subject matter. Indicators for measuring teaching creativity encompass the ability to think fluently, rationally, elaborately, and evaluate (Juandi \& Sontani, 2017). Based on this relationship, direct and indirect hypotheses are posited as follows:

\section{Training Effectiveness Affects Teaching Creativity}

Educational institutions must try to obtain quality teaching staff because the teaching staff's quality encourages a quality teaching and learning process. Previous research has shown that a qualified teacher can promote teaching creativity with various teaching behaviors and increase learning outcomes with higher test scores (Araujo et al., 2016). Another study has shown that the quality of teachers indicated by the certification of formal certification bodies impacts their teaching effectiveness compared to non-certified ones (Livingston, 2010). Furthermore, to promote the development of creativity, research-based teaching requires the teacher's imagination (Brinkman, 2010).

Teacher quality is achieved not instantaneously but through a long process. Teacher quality will result in cognitive flexibility, which, in turn, will lead to creative behavior, including innovative teaching (Sternberg, 2010). Teacher quality is characterized by skills, knowledge, experience, and education or skills, while motivation and competence are the driving force behind creativity (Hodges, 2005; Zulfija et al., 2013).

Teachers ' teaching creativity is also interpreted as a part of their pedagogical competence. Invention is interpreted as the ability to use learning methods or techniques that appeal to students (Ladson-Billings, 1995) or attractive learning designs (Goodyear, 2015). Another view is that teacher creativity can combine different skills from knowledge, attitudes, and social aspects. The teacher's teaching creativity in this study includes the teacher's ability to manage and generate new ideas in delivering the subject matter. Indicators for measuring teacher creativity teaching are that a teacher can think fluently, flexibly, rationally, detail, or in fact, and evaluate or evaluate (Karwowski et al., 2007). Based on this relationship, direct and indirect hypotheses are posited as follows:

\section{Conceptual Framework}

Teaching innovation is linked to a teacher's ability to build a conducive environment in which students feel relaxed learning by combining and connecting ideas to find multiple solutions to problems. An instructor is someone who helps students understand science and learn specific 
skills. Teachers, in general, have a broad role; this is part of their scientific responsibility. It cannot separate students' success in learning from teachers' creativity, motivating and creating a harmonious, conducive, and enjoyable learning atmosphere. To determine the level of student success in learning is necessary to hold measurements and assessments that vary according to need. That way, the results of the evaluation will be more accurate. Thus, the researcher made a temporary conclusion that to produce high student achievement; teachers must hone their creative abilities as much as possible.

The relationship between variables, either directly or indirectly, can be illustrated in the conceptual framework in Figure 1, as the hypothesis has been set out in the review literature. The variables and their measurements and indicators for each variable can be found in Table 1 below:

\section{Figure 1}

Conceptual Framework

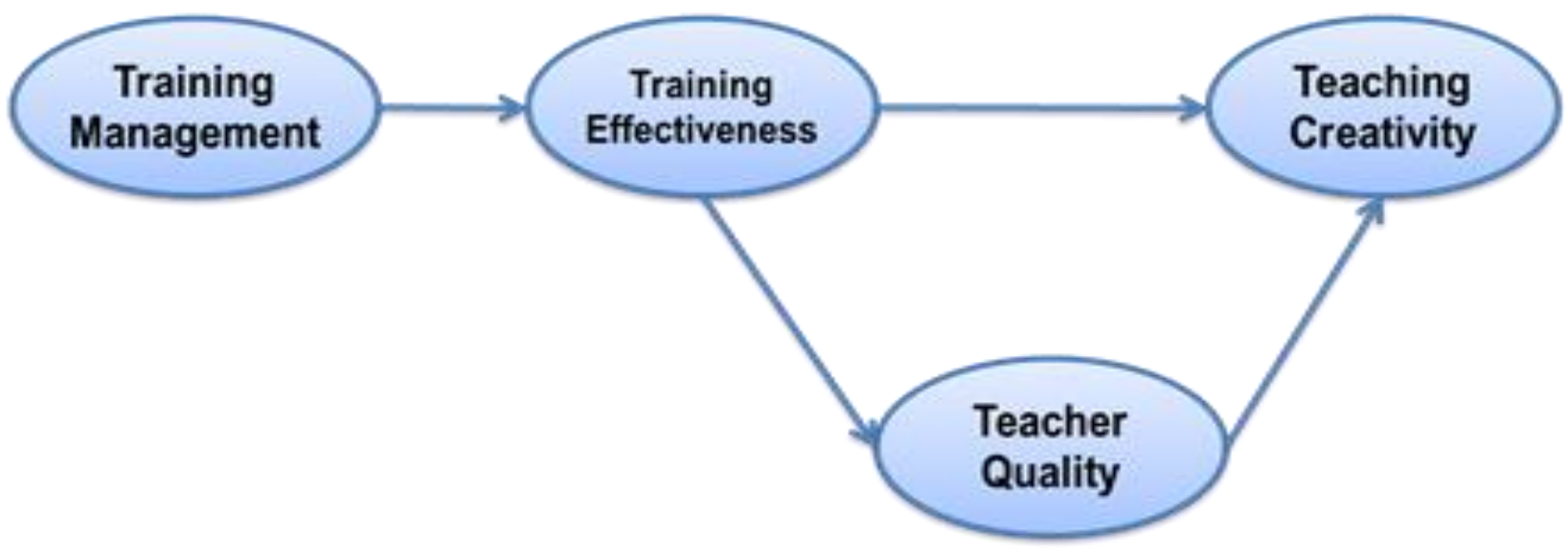

\section{Methodology}

This study uses a quantitative approach, this approach departs from a theoretical framework, the ideas of experts, and the understanding of researchers based on their experience. It is developed into problems and solutions proposed to obtain justification or assessment in the form of support for empirical data in the field. SEM-Amos version 23 was the analytical tool used; the population was all school teachers in Indonesia's South Sulawesi Province. The study used a nonprobability convenience sample based on teachers willing to complete an online questionnaire, with a sampling target of at least 200 people returning; this is because the quantitative approach will work well with SEM-Amos if it has between 100 and 200 respondents. The survey was sent to 417 respondents using Indonesian.

A respondent number was assigned to each incoming questionnaire if all statements in the questionnaire are fully completed. Only fully completed questionnaires were used. The online survey was distributed to 417 teachers. The survey was available from April to May. By the termination date, 417 teachers from the South Sulawesi Province had completed the questionnaire.

Data on the characteristics of respondents by gender can see in table 1: 
Table 1

Characteristics of Participants by Gender

\begin{tabular}{lcc}
\hline Gender & \multicolumn{1}{c}{ Amount } & Percentage \\
\hline Man & 158 teachers & $37.9 \%$ \\
Women & 259 teachers & $62.1 \%$ \\
Amount & 417 teachers & $100 \%$ \\
\hline
\end{tabular}

Source: South Sulawesi Education Office

Table 1 shows that teachers in South Sulawesi Province are dominated by female teachers at $62.1 \%$, while male teachers are $37.1 \%$. Data on participants by age can see in table 2:

Table 2

Characteristics of Participants by Age

\begin{tabular}{llc}
\hline Age & \multicolumn{1}{c}{ Amount } & Percentage \\
\hline $50-60$ Years & 97 teachers & $23.3 \%$ \\
$40-49$ Years & 124 teachers & $29.7 \%$ \\
$30-39$ Years & 152 teachers & $36.4 \%$ \\
$20-29$ Years & 44 teachers & $10.6 \%$ \\
Amount & 417 teachers & $100 \%$ \\
\hline
\end{tabular}

Source: South Sulawesi Education Office

From table 2, it can see that more than half of the total teachers in South Sulawesi Province are of productive age, namely those aged 30-39 years with a total percentage of 36.5\%. Age 40-49 years with a real rate of $29.7 \%$. Data on participants according to their education level can see in table 3:

Table 3

Characteristics of Participants by Education Level

\begin{tabular}{llc}
\hline Education Level & \multicolumn{1}{c}{ Amount } & Percentage \\
\hline Doctoral Education & 26 teachers & $6.2 \%$ \\
Masters Education & 114 teachers & $27.3 \%$ \\
Undergraduate Education & 277 teachers & $66.4 \%$ \\
Amount & 417 teachers & $100 \%$ \\
\hline
\end{tabular}

Source: South Sulawesi Education Office

From table 3, it can see that the level of teacher education includes undergraduate education of $66.4 \%$, master's education of $27.3 \%$, and doctoral education of $6.2 \%$. Questions and indicators for the survey were collected from previous articles listed in table 4 . The table shows the primary references used as the basis for determining each of these variables' indicators, which formed the basis for the questionnaire.

Training management measure by three dimensions: the Accuracy of Training Methods with indicators of suitability of the method to the background, the compatibility of the process with the career path, suitability of the technique, and training facilities (Erffmeyer \& Johnson, 1997; Wagonhurst, 2002). The second dimension, Quality of Training Content with indicators of completeness of the material, material as needed, new expertise, the order in the arrangement of matter (Christiansen et al., 1996; Pettijohn \& Pettijohn, 1994). The third dimension, Quality of 
Trainer with indicators of trainer experience, transfer material, trainer knowledge (Analoui, 1994). Training effectiveness measure by hands of additional expertise, ability to remember, and ability to practice (Perdue et al., 2002; Wilson et al., 2002) and then also investigated in public organizations (Tamsah et al., 2020). The Teacher Quality variable measure by indicators of skill, knowledge, experience, and education modified from several researchers' views (Goldhaber \& Anthony, 2003; Ogunkola \& Archer-Bradshaw, 2013; Wiswall, 2013). And the variable of Teaching Creativity is measured by indicators evaluating ability, elaborating ability, analytical thinking ability, flexible thinking ability, and fluent thinking ability (Juandi \& Sontani, 2017; Karwowski et al., 2007; Mohammad et al., 2015). in Table 4 below.

Table 4

Measurement Variables

\begin{tabular}{|c|c|c|}
\hline Variable & Indicators & $\begin{array}{c}\text { Major } \\
\text { References }\end{array}$ \\
\hline $\begin{array}{l}\text { Accuracy of Training } \\
\text { Methods }\end{array}$ & $\begin{array}{l}\text { Suitability of the method to the background } \\
\text { The compatibility of the method with the } \\
\text { career path } \\
\text { Suitability of the method and training } \\
\text { facilities }\end{array}$ & $\begin{array}{l}\text { (Erffmeyer \& } \\
\text { Johnson, 1997; } \\
\text { Wagonhurst, } \\
\text { 2002) }\end{array}$ \\
\hline Quality of Training Content & $\begin{array}{l}\text { Completeness of the material } \\
\text { Material as needed } \\
\text { New expertise } \\
\text { Order in the arrangement of matter } \\
\text { Trainer experience }\end{array}$ & $\begin{array}{l}\text { (Christiansen et } \\
\text { al., 1996; } \\
\text { Pettijohn \& } \\
\text { Pettijohn, 1994) }\end{array}$ \\
\hline Quality of Trainer & $\begin{array}{l}\text { The ability to transfer material } \\
\text { Trainer knowledge }\end{array}$ & (Analoui, 1994) \\
\hline Training Effectiveness & $\begin{array}{l}\text { Additional knowledge } \\
\text { Ability to remember } \\
\text { Ability to practice } \\
\text { Skill }\end{array}$ & $\begin{array}{l}\text { (Perdue et al., } \\
\text { 2002; Wilson et } \\
\text { al., 2002) }\end{array}$ \\
\hline Teachers Quality & $\begin{array}{l}\text { Knowledge } \\
\text { Experience } \\
\text { Education }\end{array}$ & $\begin{array}{l}\text { (Juandi \& Sontani, } \\
\text { 2017) }\end{array}$ \\
\hline Teaching Creativity & $\begin{array}{l}\text { Evaluating ability } \\
\text { Elaborating ability } \\
\text { Rational thinking ability } \\
\text { Flexible thinking ability } \\
\text { Fluent thinking ability }\end{array}$ & $\begin{array}{l}\text { (Juandi \& } \\
\text { Sontani, 2017; } \\
\text { Karwowski et al., } \\
\text { 2007; Mohammad } \\
\text { et al., 2015) }\end{array}$ \\
\hline
\end{tabular}

\section{Data Analysis}

Based on the model test performed on each variable, all indicators based on the references used in this study resulted in a loading factor greater than 0.4. These results indicate that all indicators of the variables studied were indicators of all these variables so that it was possible to proceed with the data analysis process. The initial model is the same as this study's final model (see Figure 2). 
The SEM-Amos test results were carried out after confirming that all indicators can be used for the next process. The results showed that all the direct relationships built into the model had positive and significant values (sig.>0.05). Table 5 shows the loading factor, C.R, and significance.

Table 5

The Goodness of Fit Model

\begin{tabular}{|c|c|c|c|c|c|c|c|}
\hline \multirow{2}{*}{$\begin{array}{l}\begin{array}{l}\text { Variable } \\
\text { Relationship }\end{array} \\
\text { TE }\end{array}$} & \multicolumn{3}{|c|}{ Standardized Estimate } & \multirow{2}{*}{$\begin{array}{c}\text { Estimate } \\
, 795\end{array}$} & \multirow{2}{*}{$\begin{array}{r}\text { S.E. } \\
, 054\end{array}$} & \multirow{2}{*}{$\begin{array}{c}\text { C.R. } \\
14,675\end{array}$} & \multirow{2}{*}{$\frac{\mathbf{p}}{* * *}$} \\
\hline & $<--$ & TM & ,877 & & & & \\
\hline $\mathrm{TQ}$ & $<--$ & $\mathrm{TE}$ & ,831 &, 817 & ,062 & 13,183 & $* * *$ \\
\hline $\mathrm{TC}$ & $<--$ & $\mathrm{TE}$ & 297 & 357 & ,097 & 3,667 & $* * *$ \\
\hline $\mathrm{TC}$ & $<--$ & TQ &, 517 & ,632 & 101 & 6,243 & $* * *$ \\
\hline QTC & $<--$ & $\mathrm{TM}$ & 1,005 & 951 & 053 & 17,812 & $* * *$ \\
\hline ATM & $<--$ & $\mathrm{TM}$ & ,930 & 1,000 & & & \\
\hline QOT & $<--$ & $\mathrm{TM}$ & 856 &, 871 & ,059 & 14,832 & $* * *$ \\
\hline TOTY1.1 & $<--$ & $\mathrm{TE}$ & ,767 & 1,000 & & & \\
\hline TOTY1.2 & $<--$ & $\mathrm{TE}$ & 817 &, 976 &, 058 & 16,921 & $* * *$ \\
\hline TOTY1.3 & $<--$ & $\mathrm{TE}$ & 812 &, 989 &, 059 & 16,813 & $* * *$ \\
\hline TOTY3.3 & $<--$ & $\mathrm{TC}$ & 889 & 1,000 & & & \\
\hline TOTY3.4 & $<--$ & $\mathrm{TC}$ & 852 & ,954 & ,039 & 24,621 & $* * *$ \\
\hline TOTY3.5 & $<--$ & $\mathrm{TC}$ & ,857 & 1,510 &, 062 & 24,425 & $* * *$ \\
\hline TOTY3.2 & $<--$ & $\mathrm{TC}$ & 900 & ,999 & ,036 & 27,464 & $* * *$ \\
\hline TOTY2.4 & $<--$ & TQ & ,726 & 1,000 & & & \\
\hline TOTY2.3 & $<--$ & TQ & 841 & 1,085 & ,063 & 17,180 & $* * *$ \\
\hline TOTY2.2 & $<--$ & TQ & 906 & 1,090 & ,060 & 18,038 & $* * *$ \\
\hline TOTY3.1 & $<--$ & $\mathrm{TC}$ & 856 & 1,024 & ,042 & 24,508 & $* * *$ \\
\hline TOTY2.1 & $<--$ & TQ & 863 & 1,017 & 060 & 17,011 & $* * *$ \\
\hline ТОТХ1.3 & $<--$ & ATM & 853 & 1,000 & & & \\
\hline TOTX1.2 & $<--$ & ATM & 688 &, 834 & ,055 & 15,301 & $* * *$ \\
\hline TOTX1.1 & $<--$ & ATM & ,747 &, 944 & 055 & 17,213 & $* * *$ \\
\hline TOTX2.3 & $<--$ & QTC & ,798 & 1,000 & & & \\
\hline TOTX2.2 & $<--$ & QTC & ,768 & 1,041 & ,060 & 17,314 & $* * *$ \\
\hline TOTX2.1 & $<--$ & QTC & 863 & 1,101 & ,054 & 20,235 & $* * *$ \\
\hline TOTX3.3 & $<--$ & QOT & ,773 & 1,000 & & & \\
\hline TOTX3.2 & $<--$ & QOT & ,839 & 1,066 & ,059 & 18,153 & $* * *$ \\
\hline TOTX3.1 & $<--$ & QOT & ,857 & 1,017 & 057 & 17,747 & $* * *$ \\
\hline TOTX2.4 & $<--$ & QTC & 807 & 1,067 & 057 & 18,735 & $* * *$ \\
\hline
\end{tabular}




\section{Results}

Testing for hypotheses in Table 6 shows that the overall variables tested had a positive and significant effect. The impact of training management on training efficiency, then training efficiency on teacher quality and teaching creativity, was at a $1 \%$ level of relevance. Thus, the $\mathrm{H} 1$, H2, H3, H4, and H5, were accepted. Figures 2 and 3 show more complete results.

Figure 2 shows complete research results and the value of the direct influence coefficient between variables following the hypothesis (H1-H4). Table 3 shows the indirect effect (H5).

\section{Figure 2}

\section{Direct and Indirect Effect Analysis}

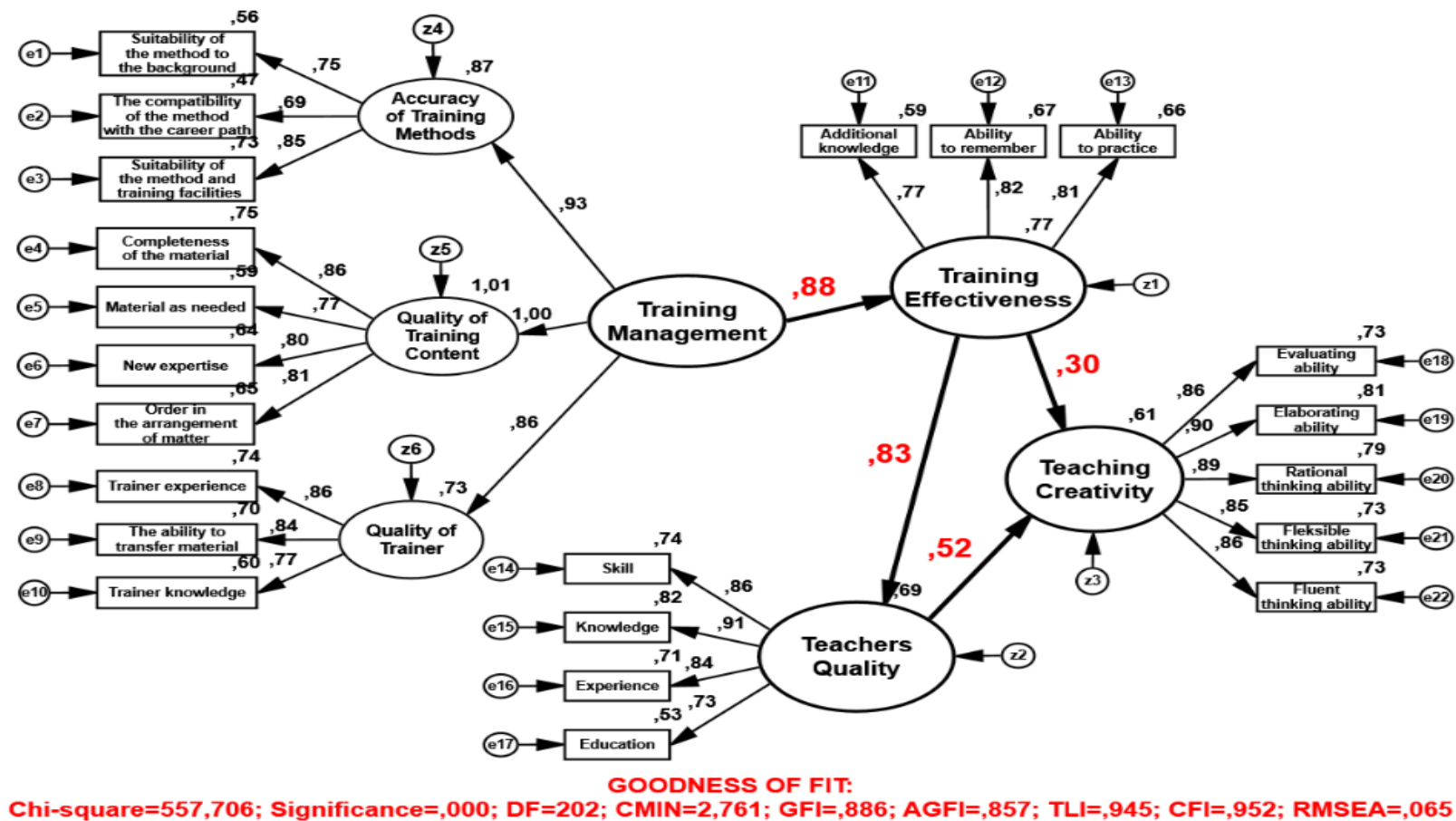

Figure 2 shows the results of $\mathrm{H} 1-\mathrm{H} 4$ testing with the SEM-Amos test. The final model produced in this study has a goodness of fit as indicated by CMIN / DF = 2.76; GFI = 0.89; AGFI $=0.86 ; \mathrm{TLI}=0.95 ; \mathrm{CFI}=0.95 ; \mathrm{RMSEA}=0.07$. Because some of the criteria were meet, especially TLI $(0.91 \geq 0.90)$, CFI $(0.93 \geq 0.90)$, and RMSEA $(0.07 \leq 0.08)$, this model is considered good and meets the requirements (Byrne, B. M., 2010).

Table 6 shows the study's overall results hypotheses $(\mathrm{H} 1-\mathrm{H} 4)$ had an acceptable direct effect. In the first hypothesis, training management was found to have a direct affect with a regression coefficient value of 0.88 and a regression value of 0.00 (less than 0.05 ). As a result, the better the training management, the more influential the training will be, and vice versa. Interestingly, the quality of the training content plays a significant role in the direction of the movement, followed by the training methods' suitability. Hence, trainer quality plays the smallest part, although significant, with a loading factor above 0.4 (Harris \& Sass, 2011). This result is consistent with previous research (Tikly \& Barrett, 2011; Wheeler \& Wheeler, 2009), and research studying precision training methods for training effectiveness (Feng \& Sass, 2017), the quality of training content for training efficiency (Johnson, 1962) and the quality of training trainers (Dwyer \& Stufflebeam, 2004). 
Table 6

Hypothesis Result

\begin{tabular}{ccccc}
\hline Variable Relationship & Estimate & C.R & p & Remark \\
\hline H1: training management $\rightarrow$ training effectiveness & $\mathbf{0 , 8 7 7}$ & $\mathbf{1 4 , 6 7 5}$ & $* * *$ & Supported \\
H2: training effectiveness $\rightarrow$ teacher quality & $\mathbf{0 , 8 3 1}$ & $\mathbf{1 3 , 1 8 3}$ & $* * *$ & Supported \\
H3: training effectiveness $\rightarrow$ teaching creativity & $\mathbf{0 , 2 9 7}$ & $\mathbf{3 , 6 6 7}$ & $* * *$ & Supported \\
H4: teacher quality $\rightarrow$ teaching creativity & $\mathbf{0 , 5 1 7}$ & $\mathbf{6 , 2 4 3}$ & $* * *$ & Supported \\
H5: training effectiveness $\rightarrow$ teacher quality $\rightarrow$ teaching & $\mathbf{0 , 4 3 0}$ & $\mathbf{4 , 7 8 1}$ & $* * *$ & Supported \\
creativity
\end{tabular}

$* * *=\mathrm{x}$.

The effect of training efficiency on teacher quality and teaching creativity had a regression coefficient of 0.831 and 0.297 and a regression rate of 0.00 less than 0.05 . Thus, the effectiveness of training directly affects the quality of teachers and the quality of teaching. If the exercise point is improved, then the quality of education and the creativity of teaching teachers will also be improved and vice versa. In the relationship between training efficiency and teacher quality, and teaching creativity, the ability to remember is the indicator with the most significant contribution (0.82) compared to the other two indicators. However, the other two indicators also offer a considerable contribution ( 0.81 and 0.77 , respectively). This shows that the ability factors resulting from training have a significant role in improving teacher quality and teaching creativity. This result is consistent with previous findings that adequate training will lead to the development of a professional teacher (Sachs, 2001) if a teacher's professionalism is one of a quality teacher's characteristics. Different education and training types can boost teachers' productivity by increasing student achievement (Bickmore \& Bickmore, 2010), where education is a hallmark of quality teachers. Furthermore, training effectiveness can facilitate the development of a creative process (Berg et al., 2014).

The is study also shows that teaching quality can improve teaching creativity, as demonstrated by the acceptance of the fourth hypothesis. The resultant regression coefficient was 0.517 , and the value was 0.00 less than 0.05 , which indicates that the teacher's quality directly affects the teaching of creativity. This result means that the better the teacher's quality, the higher the teacher's creative instruction. The quality of teacher knowledge indicator has the most generous contribution to teaching creativity. Thus, an increase in teachers' quality, marked by an increase in knowledge, skills, experience, and educational level because of practical training, encourages growth in teaching creativity. These results justify the research hypothesis and are consistent with Muhson (2012); However, they do not explicitly indicate teachers' quality, but certification and professionalism are quality teachers' characteristics. Teacher quality is characterized by competence, knowledge, experience, and education. In contrast, motivation and competence are the driving force behind creativity (Tan, 2014), and standardization, as the driving force behind creativity (Sternberg, 2003); standardization is a requirement for teacher quality.

The indirect effect of training effectiveness on teaching creativity through teachers' quality was also significant, so hypothesis 5 was accepted. The indirect effect coefficient is 0.430 with a t-count value (see Figure 3) of 4.781, more significant than 1.96 as a requirement of significance (Zulfija et al., 2013). Thus, the value of the indirect effect is greater than that of the direct impact. These results indicate that the teacher's quality is a pure mediator. Effective training will improve a teacher's education and encourage an increase in teacher creativity. 
Figure 3

Sobel Test Results

\section{- TE $\rightarrow$ TQ $\rightarrow$ TC}

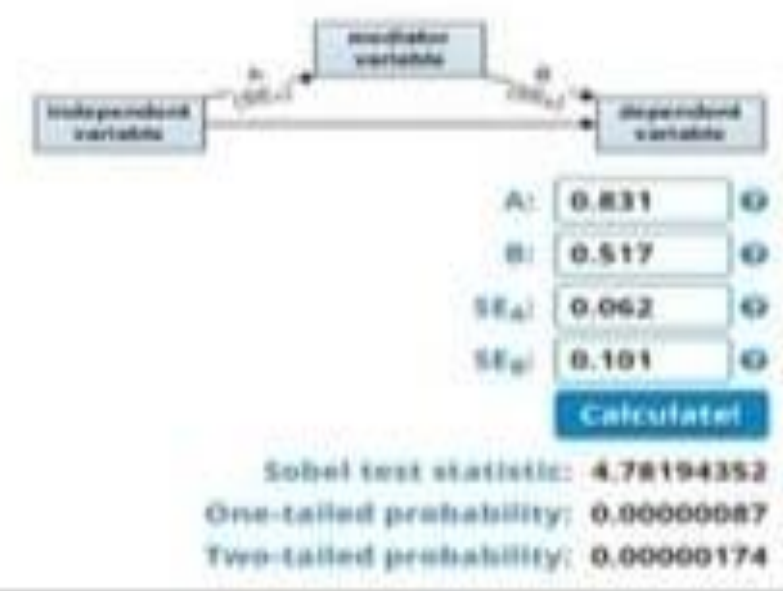

Direet effecti

$\mathrm{TE} \rightarrow \mathrm{TC}=0.297^{*}$

Indirect Effect:

$\mathrm{TE} \rightarrow \mathrm{TQ} \rightarrow \mathrm{TC}=0,430^{\circ}$

\section{Discussion and Conclusion}

Being a teacher is a challenging profession. Many teachers have been effective in assisting their students' academic growth and the development of their personalities. Teachers instill totality and selflessness in their students by encouraging commitment to education. Good teachers enjoy their jobs, believe in the content they teach, work hard, spend a lot of time planning lesson plans, use parenting styles, care for their student's needs, and strive to engage all students in learning. Becoming a creative teacher is not something that happens overnight; it is a long process (Amanda et al., 2017). As a result, to become an inspiring teacher, someone must sustain the determination to continue to provide students with imaginative, inspirational, and inventive spirits. Teachers can create superior students who are full of creativity and competitive abilities. Teachers are role models for their students, so before they grant their students' wishes, teachers must be imaginative, inspiring, inventive, and efficient.

Teachers confronted with the complexities of the Covid-19 pandemic must be highly creative in the online learning environment. A teacher is a technical position directly connected to education and engaging with students requires a high degree of imagination. A teacher's role as both an instructor and instilling good characteristics in a student cannot be ignored. Teachers must do everything possible to ensure that students are well served. The Covid-19 pandemic requires teachers to think creatively in their classrooms. A teacher who does not dare to think creatively will face additional obstacles if he wishes to improve the way he teaches. The teacher's challenge is to modify the online learning structure (Gustina \& Sweet, 2014). Not all teachers are prepared to deal with educational system changes - especially teachers in areas with limited access to online learning system resources and networks. Students must also adapt to and understand more about the online learning system's applications.

Teachers' challenges in the online learning environment are part of the educational dynamics of the Covid-19 era. As the secret to good learning, a teacher must strive to increase innovation in the classroom. Teachers must be more innovative when coping with online learning issues. This innovation is linked to teachers' ability to adjust teaching models, to teachers' ability 
to correct flaws in practices or teaching phases, to teachers' ability to pursue new concepts, to teachers' ability to take advantage of developments in technology media, and to a variety of other significant abilities associated with innovative teacher categories.

The most critical figure is the teacher because it is a teacher's responsibility to educate. However, not all teachers can inspire their students (Livingston, 2010). Teachers who can encourage their students are true educators. Students will interpret what they learn if they are taught by an inspiring instructor, even if it is unrelated to their school's curriculum. An inspiring teacher is not one who merely follows a program. An instructor should invite students to think creatively, see things from the outside, change it from the inside, and then put it back outside, to a larger group. Inspiring teachers give birth to reformer leaders who are willing to break old practices that are no longer useful (Jeffrey \& Craft, 2004).

An instructor may serve as a facilitator, a guide, a provider of an environment, a model, a motivator, or a cognitive development agent. As a facilitator, the instructor serves as a learning service provider, making it easier for students to obtain the information or expertise they need. The instructor will act as a mentor by assisting students who are experiencing difficulties (Simonton, 2012). As an atmosphere provider, an instructor tries to plan and build a learning environment that is enjoyable and challenging based on student needs and circumstances so that passion for learning can emerge. The teacher's job as a model is to provide good role models following societal norms. The teacher as a motivator is the teacher who constantly motivates students to learn and be conscious of their potential. As an agent of cognitive growth, an instructor is responsible for disseminating information to students to be applied in their experiences.

Efficiency in training is the key to developing the quality and creativity of teaching teachers to achieve the learning process's objectives. Still, the effectiveness of training is strongly influenced by good training management. Teacher training's effectiveness can encourage improvement in quality and increase the creativity of teaching. Suppose movement is correctly managed by paying attention to the method's suitability with the type and activity participants, paying attention to the quality of the content, and improving the instructors' quality. In that case, this will have an impact on the effectiveness of the training. Significant training will further enhance the quality and creativity of teaching teachers. Training effectiveness can increase teaching creativity, and teachers' quality can be a good mediator between training and teaching creativity. The is study's results help bridge a knowledge gap in explaining how well-managed training will result in practical training. Lastly, this study found that good quality teachers will encourage increased teaching creativity.

\section{References}

Amanda, M. P., Humaedi, S., \& Santoso, M. B. (2017). Penyalahgunaan narkoba di kalangan remaja [Adolescent substance abuse]. Prosiding Penelitian Dan Pengabdian Kepada Masyarakat, 4(2), 129-389. https://doi.org/10.24198/jppm.v4i2.14392

Analoui, F. (1994). Training and development. Journal of Management Development, 13(8), 6172. https://doi.org/http://dx.doi.org/10.1108/02621719410072107

Araujo, M. C., Carneiro, P., Cruz-Aguayo, Y., \& Schady, N. (2016). Teacher quality and learning outcomes in kindergarten. Quarterly Journal of Economics, 1(1), 11-17. https://doi.org/10.1093/qje/qjw016

Baer, J. (2020). Teaching creativity. In S. Pritzker \& M. Runco (Eds.), Reference module in neuroscience and biobehavioral psychology: Encyclopedia of creativity (3rd ed., pp. 540546). Academic Press. https://doi.org/10.1016/B978-0-12-809324-5.21916-0 
Barro, R. J. (2001). Human capital and growth. American Economic Review, 91(2), 12-17. https://doi.org/10.1257/aer.91.2.12

Berg, J. H., Carver, C. L., \& Mangin, M. M. (2014). Teacher leader model standards: Implications for preparation, policy, and practice. Journal of Research on Leadership Education, 9(2), 195-217. https://doi.org/10.1177/1942775113507714

Bickmore, D. L., \& Bickmore, S. T. (2010). A multifaceted approach to teacher induction. Teaching \& Teacher Education, 26(4), 1006-1014. https://doi.org/10.1016/j.tate.2009.10.043

Bohacek, R., \& Kapicka, M. (2008). Optimal human capital policies. Journal of Monetary Economics, 55(1), 1-16. https://doi.org/https://doi.org/10.1016/j.jmoneco.2007.10.007

Brent, E., \& Leedy, P. D. (1990). Practical research: Planning and design. Teaching Sociology, 18(2), 248-249. https://doi.org/10.2307/1318509

Brinkman, D. J. (2010). Teaching creatively and teaching for creativity. Arts Education Policy Review, 111(2), 48-50. https://doi.org/10.1080/10632910903455785

Brown, S., Gray, D., McHardy, J., \& Taylor, K. (2015). Employee trust and workplace performance. Journal of Economic Behavior and Organization, 12(25), 361-378. https://doi.org/10.1016/j.jebo.2015.05.001

Byrne, B. M. (2010). Structural equation modeling with AMOS: basic concepts, applications, and programming (multivariate applications series). New York: Taylor \& Francis Group, $396(1), 7384$.

Chatani, K. (2012). Human capital and economic development. In H. Hill, M. Khan, \& J. Zhuang (Eds.), Diagnosing the Indonesian economy: Toward inclusive and green growth (pp. 275300). Anthem Press. https://doi.org/10.7135/UPO9781843313786.010

Christiansen, T., Evans, K. R., Schlacter, J. L., \& Wolfe, W. G. (1996). Training differences between services and goods firms: Impact on performance, satisfaction, and commitment.

Journal of Professional Services Marketing, 15(1), 47-70. https://doi.org/10.1300/J090v15n01_04

Daniel, S. J. (2020). Education and the COVID-19 pandemic. Prospects, 49, 91-96. https://doi.org/10.1007/s11125-020-09464-3

Dehaan, R. L. (2009). Teaching creativity and inventive problem solving in science. CBE Life Sciences Education, 8(3), 172-181. https://doi.org/10.1187/cbe.08-12-0081

Dinda, S. (2014). Inclusive growth through creation of human and social capital. International Journal of Social Economics, 41(10), 878-895. https://doi.org/https://doi.org/10.1108/IJSE-07-2013-0157

Dobson, S. (1985). Teacher quality. British Journal of In-Service Education, 11(3), 145-153. https://doi.org/10.1080/0305763850110306

Dwyer, C. A., \& Stufflebeam, D. (2013). Teacher evaluation. In D. C. Berliner \& R. C. Calfee (Eds.), Handbook of educational psychology. Routledge. https://doi.org/10.4324/9780203053874-32

Erffmeyer, R. C., \& Johnson, D. A. (1997). The future of sales training: Making choices among six distance education methods. Journal of Business and Industrial Marketing, 12(3-4), 185-195. https://doi.org/10.1108/08858629710188027

Favale, T., Soro, F., Trevisan, M., Drago, I., \& Mellia, M. (2020). Campus traffic and e-Learning during COVID-19 pandemic. Computer Networks, 176. https://doi.org/10.1016/j.comnet.2020.107290

Feng, L., \& Sass, T. R. (2017). Teacher quality and teacher mobility. Education Finance \& Policy, 12(3), 396-418. https://doi.org/10.1162/EDFP_a_00214 
Florea, N. M., \& Hurjui, E. (2015). Critical thinking in elementary school children. Procedia Social \& Behavioral Sciences, 180, 565-572. https://doi.org/10.1016/j.sbspro.2015.02.161

Flournoy, E., Turner, G., \& Combs, D. (2000). Innovative teaching. Dimensions of Critical Care Nursing, 19(4), 36-37. https://doi.org/10.1097/00003465-200019040-00012

Gagné, M. (2009). A model of knowledge-sharing motivation. Human Resource Management, 48(4), 571-589. https://doi.org/10.1002/hrm.20298

Goldhaber, D., \& Anthony, E. (2003). Indicators of Teacher Quality. ERIC Digest. https://eric.ed.gov/?id=ED478408

Goodyear, P. (2015). Teaching as design. HERDSA Review of Higher Education, 2, 27-50.

Guskey, T. R. (2002). Professional development and teacher change. Teachers \& Teaching: Theory and Practice, 8(3), 381-391. https://doi.org/10.1080/135406002100000512

Gustina, C., \& Sweet, R. (2014). Creatives teaching creativity. International Journal of Art \& Design Education, 33(1), 46-54. https://doi.org/10.1111/j.1476-8070.2014.01778.x

Hannah, L. (1987). Human capital. Oxford Review of Education, 13(2), 177-181. https://doi.org/10.1080/0305498870130205

Harris, D. N., \& Sass, T. R. (2011). Teacher training, teacher quality and student achievement. $\begin{array}{llll}\text { Journal of Public } & \text { Economics, }\end{array}$ https://doi.org/10.1016/j.jpubeco.2010.11.009

Hodges, G. C. (2005). Creativity in education. English in Education, 39(3), 47-61. https://doi.org/10.1111/j.1754-8845.2005.tb00624.x

Hollins, E. R. (2011). Teacher preparation for quality teaching. Journal of Teacher Education, 9(11), 395-407. https://doi.org/10.1177/0022487111409415

Jeffrey, B., \& Craft, A. (2004). Teaching creatively and teaching for creativity: Distinctions and $\begin{array}{llll}\text { relationships. } & \text { Educational } & \text { Studies, } & \text { 30(1), }\end{array}$ https://doi.org/10.1080/0305569032000159750

Johnson, D. P. (1962). Teacher effectiveness. Journal of Teacher Education, 13(1), 102-102. https://doi.org/10.1177/002248716201300123

Joll, C., Mckenna, C., Mcnabb, R., Shorey, J., Joll, C., Mckenna, C., Mcnabb, R., \& Shorey, J. (2019). Human capital theory. In C. Joll, C. Mckenna, R. Mcnabb, \& J. Shorey (Eds.), Developments in labour market analysis. Routledge. https://doi.org/10.4324/9780429025204-4

Juandi, A., \& Sontani, U. T. (2017). Keterampilan dan kreativitas mengajar guru sebagai determinan terhadap prestasi belajar siswa. Jurnal Pendidikan Manajemen Perkantoran, 2(2), 130. https://doi.org/10.17509/jpm.v2i2.8114

Juklová, K. (2015). Reflection in prospective teacher training. Procedia - Social and Behavioral Sciences, 171, 891-896. https://doi.org/10.1016/j.sbspro.2015.01.206

Karwowski, M., Gralewski, J., Lebuda, I., \& Wiśniewska, E. (2007). Creative teaching of creativity teachers: Polish perspective. Thinking Skills \& Creativity, 2(1), 57-61. https://doi.org/10.1016/j.tsc.2006.10.004

Ladson-Billings, G. (1995). Toward a theory of culturally relevant pedagogy. American Educational Research Journal, 24(12), 465-491. https://doi.org/10.3102/00028312032003465

Livingston, L. (2010). Teaching creativity in higher education. Arts Education Policy Review, 111(2), 59-62. https://doi.org/10.1080/10632910903455884

Mohammad, N., Yasin, R. M., \& Ana. (2015). creative teaching in design and technology curriculum: Using Structural Equation Modeling. Procedia - Social \& Behavioral Sciences, 204(2014), 240-246. https://doi.org/10.1016/j.sbspro.2015.08.146 
Muhson, A. (2004). Meningkatkan Profesionalisme Guru: Sebuah Harapan. Jurnal Ekonomi Dan Pendidikan, 1(2), 90-98. https://doi.org/https://doi.org/10.21831/jep.v1i2.665

Nigam, K., \& Ghani, R. (2000). Analyzing the effectiveness and applicability of co-training. In Proceedings of the ninth international conference on information and knowledge management (pp. 86-93). Association for Computing Machinery. https://doi.org/10.1145/354756.354805

Ogunkola, B. J., \& Archer-Bradshaw, R. E. (2013). Teacher quality indicators as predictors of instructional assessment practices in science classrooms in secondary schools in Barbados. Research in Science Education, 43(1), 3-31. https://doi.org/10.1007/s11165-011-9242-5

Pencheon, D., \& Koh, Y. M. (2000). Leadership and motivation. BMJ (Clinical research ed.), 321(7256), S2-S7256. https://doi.org/10.1136/bmj.321.7256.s2-7256

Perdue, J., Ninemeier, J. D., \& Woods, R. H. (2002). Training methods for specific objectives: Preferences of managers in private clubs. International Journal of Contemporary Hospitality Management, 14(3), 114-119. https://doi.org/10.1108/09596110210424402

Pettijohn, L. S., \& Pettijohn, C. E. (1994). Retail sales training: Practices and prescriptions. Journal of Services Marketing, 8(3), 17-26. https://doi.org/http://dx.doi.org/10.1108/08876049410065570

Sachs, J. (2001). Teacher professional identity: Competing discourses, competing outcomes. Journal of Education Policy, 9(11), 149-161. https://doi.org/10.1080/02680930116819

Schipper, L. (1984). Innovative teaching. Improving College \& University Teaching, 32(1), 54-57. https://doi.org/10.1080/00193089.1984.10533842

Scott, G., Leritz, L. E., \& Mumford, M. D. (2004). The effectiveness of creativity training: A quantitative review. In Creativity Research Journal, 15(9), 361-388. https://doi.org/10.1080/10400410409534549

Simonton, D. K. (2012). Teaching Creativity: Current Findings, Trends, and Controversies in the Psychology of Creativity. Journal of Psychology, 39(3), 217-222. https://doi.org/https://doi.org/10.1177/0098628312450444

Šlaus, I., \& Jacobs, G. (2011). Human capital and sustainability. Sustainability, 3(1), 97-154. https://doi.org/10.3390/su3010097

Sternberg, R. J. (2003). Creative thinking in the classroom. International Journal of Phytoremediation, 14(35), 325-338. https://doi.org/10.1080/00313830308595

Sternberg, R. J. (2010). Teaching for creativity. In R. Beghetto \& J. Kaufman (Eds.), Nurturing creativity in the classroom (pp. 394-414). Cambridge University Press. https://doi.org/10.1017/CBO9780511781629.020

Tamsah, H., Ansar, Ilyas, G., Yusriadi, Y., \& Farida, U. (2020). Training, Knowledge Sharing, and Quality of Work-Life on Civil Servants Performance in Indonesia. Journal of Ethnic and Cultural Studies, 7(3), 163-176. https://doi.org/http://dx.doi.org/10.29333/ejecs/514

Tan, E. (2014). Human capital theory: A holistic criticism. Review of Educational Research, 84(3), 411-445. https://doi.org/10.3102/0034654314532696

Thomas, R. J., \& Cheese, P. (2005). Leadership: Experience is the best teacher. Strategy \& Leadership, 33(3), 24-29. https://doi.org/10.1108/10878570510594424

Tikly, L., \& Barrett, A. M. (2011). Social justice, capabilities and the quality of education in low income countries. International Journal of Educational Development, 31(1), 3-14. https://doi.org/https://doi.org/10.1016/j.ijedudev.2010.06.001

Ucus, S. (2015). Elementary school teachers' views on game-based learning as a teaching method. Procedia - Social and Behavioral Sciences, 186, 401-409. https://doi.org/10.1016/j.sbspro.2015.04.216 
Ur, P. (1992). Teacher learning. ELT Journal, 46(1) 56-61. https://doi.org/10.1093/elt/46.1.56

Van Bruggen, J. (2005). Theory and practice of online learning. British Journal of Educational Technology, 43(75), 111-120. https://doi.org/10.1111/j.1467-8535.2005.00445_1.x

Van Der Klink, M. R., \& Streumer, J. N. (2002). Effectiveness of on-the-job training. Journal of European Industrial Training, 22(19) 196-199. https://doi.org/10.1108/03090590210422076

Vorontsov, A., \& Vorontsova, E. (2015). Innovative Education in Russia: The Basic Tendencies Analysis. Procedia - Social and Behavioral Sciences, 214(1), 1147-1155. https://doi.org/https://doi.org/10.1016/j.sbspro.2015.11.731

Wagonhurst, C. (2002). Developing effective training programs.(Educational Update). Journal of Research Administration, XXXIII(II), 77-83.

West, D., \& Blackman, D. (2015). Performance management in the public sector. Australian Journal of Public Administration, 74(1), 73-81. https://doi.org/10.1111/1467-8500.12130

Wheeler, S., \& Wheeler, D. (2009). Using wikis to promote quality learning in teacher training. Learning, Media, and Technology, $34(1), \quad 1-10$. https://doi.org/10.1080/17439880902759851

Wilson, P. H., Strutton, D., \& Farris, M. T. (2002). Investigating the perceptual aspect of sales training. Journal of Personal Selling \& Sales Management, 22(2), 77-86. https://doi.org/10.1080/08853134.2002.10754296

Wiswall, M. (2013). The dynamics of teacher quality. Journal of Public Economics, 100, 61-78. https://doi.org/10.1016/j.jpubeco.2013.01.006

Wößmann, L. (2003). Specifying human capital. Journal of Economic Surveys, 17(3), 239-270. https://doi.org/10.1111/1467-6419.00195

Zacharias, T., Rahawarin, M. A., \& Yusriadi, Y. (2021). Cultural Reconstruction and Organization Environment for Employee Performance. Journal of Ethnic and Cultural Studies, 8(2), 296-315. https://doi.org/http://dx.doi.org/10.29333/ejecs/801

Zhao, P., Zhou, J., \& Li, Q. (2017). Teacher education. In W. J. Morgan, Q. Gu, \& F. Li (Eds.), Handbook of education in China: Handbooks of research on contemporary China series (pp. 140-168). Elgar Online. https://doi.org/10.4337/9781783470662.00017

Zulfija, M., Indira, O., \& Elmira, U. (2013). The Professional Competence of Teachers in Inclusive Education. Procedia - Social and Behavioral Sciences, 89(1), 549-554. https://doi.org/https://doi.org/10.1016/j.sbspro.2013.08.892 


\section{Notes on Contributors}

Hasmin Tamsah is a lecturer at Magister Program of Economic Science of Sekolah Tinggi Ilmu Ekonomi AMKOP, Makassar, Indonesia. His areas of interest and research include social science, economic, management, human resource, policy, and education. He has published some books and many articles in national and international journals. He is a reviewer and editor in some local and international journals. hasmintamsah@gmail.com, https://orcid.org/0000-0002-95709658

Jamaluddin Bata Ilyas is a lecturer at Magister Program of Economic Science of Sekolah Tinggi Ilmu Ekonomi AMKOP, Makassar, Indonesia. His areas of interest and research include economic, management, human resource, and education. He has published some books and articles in national and international journals. Jamaluddinilyas27@gmail.com, https://orcid.org/00000003-4735-0596

Yusriadi Yusriadi is a lecturer at Public Administration Department of Sekolah Tinggi Ilmu Administrasi Puangrimaggalatung, Makassar, Indonesia. His work focuses on teaching, learning, research, and community services. His areas of interest and research include social sciences, political science, sociology, legal studies, and public administration. He is a reviewer and editor of local and international journals. yusriadi.yusriadi@uqconnect.edu.au, https://orcid.org/0000-00017908-152 